\title{
MEMAHAMI KEMBALI PEMAKNAAN HADIS QUDSI
}

\author{
Abdul Fatah Idris \\ Universitas Islam Negeri (UIN) Walisongo Semarang Jawa Tengah \\ E-mail:fatah_idris@walisongo.ac.id
}

\begin{abstract}
The scholars of hadith have different viewpoints in understanding the meaning of hadith $Q u d s i$. The differences are affected by understanding of the concept of hadith Qudsi that is the the word of Allah conveyed through the words of the Prophet Muhammad. However, Hadith Qudsi is not like the Qur'an. This article will briefly show an understanding of hadith Qudsi and the Qur'an; and hadith Qudsi and Hadith Nabawi. The author agree with a view of the scholars of hadith who says that, the Hadith Qudsi is a special Hadith verbalized by Prophet both meaning and pronunciation. Therefore, there are no differences between Hadith Qudsi and the sayings of the Prophet in general. The Prophetic Hadith is classified into authentic hadith, hasan and da'eef; can also be found in hadith Qudsi. There may be some differences, in which Hadith Qudsi is not wider than Hadith Nabawi. Hadith Qudsi is not direct words of God, but only the ideas and then verbalized by the prophet himself.
\end{abstract}

Keywords: Theory of Thought of Hadith Qudsi; Understanding of the Qur'an; Understanding of Hadith Qudsi and Nabawi; Classification of Hadith Qudsi and Nabawi

\begin{abstract}
ABSTRAK
Para ulama hadis memiliki sudut pandang yang berbeda dalam memahami makna hadits Qudsi. Perbedaan tersebut dipengaruhi oleh pemahaman konsep hadis Qudsi yaitu firman Allah yang disampaikan melalui firman Nabi Muhammad SAW. Namun, Hadis Qudsi tidak seperti Alquran. Artikel ini akan secara singkat menunjukkan pemahaman tentang hadits Qudsi dan Alquran; Dan hadis Qudsi dan Hadis Nabawi. Penulis setuju dengan pandangan para ulama hadis yang mengatakan bahwa, Hadis Qudsi adalah Hadis khusus yang diucapkan secara verbal oleh Nabi baik
\end{abstract}


makna maupun pengucapannya. Oleh karena itu, tidak ada perbedaan antara Hadis Qudsi dan perkataan Nabi pada umumnya. Hadis Nabi diklasifikasikan ke dalam hadits, hasan dan da'eef yang otentik; Bisa juga ditemukan dalam hadis Qudsi. Mungkin ada beberapa perbedaan, di mana Hadis Qudsi tidak lebih luas dari Hadis Nabawi. Hadits Qudsi bukanlah kata-kata langsung dari Tuhan, tapi hanya gagasan dan kemudian diucapkan secara verbal oleh nabi sendiri.

Kata Kunci: Klasifikasi Hadis Qudsi dan Hadis Nabawi; Pemahaman AlQur'an; Pemahaman Hadis Qudsi dan Nabawi; Teori Pemikiran Hadis Qudsi

\section{A. Pendahuluan}

Para Muhädisīn dalam memahami pengertian hadis Qudsi membedakan dalam memahami pengertian hadis atau sunah Nabi pada umumnya. Hadis Qudsi disebut pula sebagai hadis Mlahiy atau Rabaniy, yakni sebuah hadis yang sama halnya seperti hadis Nabi, tetapi dimana keduanya secara subtansi (kandungan maknanya) berbeda dari asal sumbernya. Hadis Qudsi maknanya bersunber dari Allah swt, sedangkan hadis atau sunah pada umumnya bersumber dari Nabi sendiri baik lafal maupun maknanya. Namun keduanya ketika disampaikan kepada audien (umat) dilafalkan persis secara verbal oleh Nabi saw. Namun ulama hadis ketika hadis Qudsi pemaknaannya dipersamakan dengan al-Qur'an secara utuh mereka menyatakan menolak dan dengan memberikan unsur-unsur perbedaan antara keduanya. Demikian pula jika hadis Qudsi dipersamakan dengan hadis nabawi atau hadis Nabi pada umumnya mereka pun menolak, dan mereka memberi alasan-alasan atas perbedaannya. Kemudian ketika hadis Qudsi diteliti melalui kritik hadis maka para ulama hadis, menemukan sebagian hadis-hadis Qudsi ada yang diklasifikasikan sebagai hadis yang palsu (da'if).

Hadis sahih yang benar-benar bersumber dari Nabi, adalah hadis yang telah diteliti dan dievaluasi melalui sebuah kaidah-kaidah yang telah dibuat oleh para ulama hadis dan dituangkan dalam sebuah pengetahuan ('ulumul hadiś). Ilmu ini bekerja secara maksimal agar supaya tidak ada percampuran perkataan Nabi Muhammad saw, dengan laninnya. Juga untuk membedakan mana hadis yang sahih dan mana yang palsu. Dalam menentukan Sahih dan lemahnya sebuah hadis dapat ditentukan melalui kritik sanad dan kritik matan. Dua unsur ini sejak dahulu sampai sekarang 
selalu actual dijadikan perbincangan yang menarik sebagi bahan kajian para kritikus konservatif maupun modern. Kritik mereka terhadap hadis, terkadang menghasilkan perbedaan-perbedaan pandangan. Hal ini logis karena dilatarbeloakangi oleh perbedaan luasnya ilmu pengetahuan masing-masing, serta ketat dan longgarnya persyaratan kesahihan dan kelemahan sebuah hadis. Oleh karena itu kritik hadis terjadi bukan saja pada hadis-hadis Nabi secara umum, tetapi kritik dapat dilakukan pula pada hadis Qudsi.

Secara historis kritik hadis telah terjadi dimulai sejak awal Islam (masa sahabat) terhadap kritik conten (matan) maupun kritik sanad. Kritik ini berlanjut ketika para ulama Islam mengalami disintergrasi, sehingga mereka membuat hadis-hadis palsu, yang bertujuan politis dan dogmatis. Serta agar hadis-hadis tersebut dianggap sahih maka dibuatlah tranmisi (sanad) yang seolah-olah bersumber dari Nabi. Sebagaimana direfleksikan oleh J. Schacht (J. Schacht, 2010: 250), bahwa isnād adalah hasil dari perkembangan pemikiran generasi awal Islam dan isnād yang dinilai oleh ulama-ulama Islam paling tinggi adalah merupakan hasil pemalsuan-pemalsuan yang telah meluas pada generasi sebelum Imam Malik. Maka sejak itulah ulama-ulama Islam menghimpun kitab-kitab hadis sesuai dengan kapasitas mereka dari tingkat yang bermutu tingkat keabsahannya sampai pada tingkat yang terendah. yaitu kitab-kitab yang terhimpun dalam canonical collection.

Kajian ini, barangkali menjadi sebuah pemikiran penulis mengapa hadis Qudsi seolah-olah tidak terusik kritikan para kritikus. Apakah hal ini karena alasan bahwa hadis Qudsi yang secara subtansi dirumuskan sebagai wahyu dari Allah tetapi secara verbal merupakan hadis Nabi. Persoalan hadis Qudsi perlu untuk dilakukan kajian secara mendalam, yakni meninjau kembali pemaknaan hadis qudsi, karena dikatakan berbeda dengan hadis Nabi pada umumnya, tetapi ketika diverbalkan keduanya persis sama dengan ucapan dari Nabi saw. Sehingga yang menjadi permasalahan Mengapa hadis Qudsi didefinisikan sebagai hadis yang ide kontennya dari Allah namun diverbalkan oleh nabi, karenanya berbeda dengan hadis Nabi pada umumnya? Lantas, bagaimana pemahaman hadis qudsi dan al-Qur'an? 


\section{B. Pembahasan}

\section{Teori Pemikiran Hadis Qudsi}

Subkhi Shaleh, dalam bukunya, "'Ulum al-Hadits wa Muștalahuhu" menjelaskan tentang ketidaksamaan dalam pemaknaan antara hadis Qudsi dengan hadis Nabi pada umumnya. Tetapi para ulama hadis membedakan antara hadis Qudsi dengan al-Qur'an baik perbedaan itu dari segi susunan maknanya maupun jumlah dalam karakter kalimat maupun kata-katanya. Hadis Qudsi disebut pula hadis al-Ilahiy atau al-Rabaniy, yakni sebuah hadis yang sama halnya seperti hadis Nabi, tetapi dimana keduanya secara subtansi (kandungan maknanya) berbeda dari asal sumbernya. Hadis Qudsi maknanya bersunber dari Allah swt, sedangkan hadis atau sunah pada umumnya bersumber dari Nabi sendiri. Namun keduanya ketika disampaikan kepada audien (umat) dilafalkan persis secara verbal oleh Nabi saw (Subkhi Shaleh, 1978: 11-13).

Menurut William A. Graham (Graham, 1977: 51) dalam karyanya "Divine Word and Prophetic Word in Early Islam" menyebutkan bahwa jarang bagi intelek Muslim di Barat yang membahas tentang hadis Qudsi. Menurutnya bahwa hadis Qudsi pertama kali ditemukan di sebuah sumber yang diterbitkan oleh Joseph Von Hammer- Purgstall dalam sebuah artikel pada tahun 1851, ia mendefinisikan hadis tersebut sebagai "hadis yang suci atau surgawi" di mana .... Allah sendiri berbicara dan yang diwahyukan kepada nabi baik melalui Malaikat Jibril atau dalam mimpi". Hanya beberapa tahun kemudian, dalam karya yang monumental Ensyclopaedia Islam (1913-1938) Arab-Inggris oleh Leksikon EW Lane, menyebutkan secara umum hadis Qudsi sama dengan "Hadis”. Dan Ignaz Golziher-pun, tidak menyebutkan Hadis Ilahi dalam studinya tentang literatur Hadis pada Muhammedanische Studen (1889).

Jonathan A.C. Brown dalam Majalah "Islamic Law and Society" yang berjudul: "How We Know Early Hadith Critics Did Matn Criticism and Why It's So Hard to Find", menyimpulkan bahwa Sarjana Barat pada umumnya sepakat bahwa kritik awal pada sebuah hadis terfokus pada keotentikan hadis, yakni meneliti pada isnad. Karena itu kritikus Barat beralasan untuk lebih tertuju pada penelitian matan, dengan mempertimbangkan tumpuannya terhadap keraguan materi (matan) atau karya-karya yang 
dihasilkan sesudah periode formal dalam tradisi Hadith Sunni. Misalnya kritik matan dari abad III dan IV Hijriyah. Hal ini terbukti bahwa ketika formalisasi di masa Sunni, kritik Hadith tidak secara terbuka terlibat dalam kritik matan, sehingga para kritikus dengan sadar membuat image eksklusif terfokus pada isnad. Yaitu dalam rangka upaya untuk menangkis serangan dari lawan kaum rasionalis. Dengan metode menunjukkan korelasi yang kuat antara hadis yang ditemukan dalam buku-buku awal kritik isnad, dan yang ditemukan dalam buku-buku kemudian, dengan kritik matan hadits secara eksplisit. Dalam kajian ini dapat menunjukkan bahwa awal kritik buku-buku yang bergerak dalam bidang kritik matan jauh lebih sering daripada kelihatannya menyembunyikan kegiatan ini dengan menggunakan istilah kritik isnad.

William A. Graham, dalam karyanya "Divine Word and Prophetic Word in Early Islam" menyebutkan bahwa jarang bagi intelek Muslim di Barat yang membahas tentang hadis Qudsi. Menurutnya bahwa hadis Qudsi pertama kali ditemukan di sebuah sumber yang diterbitkan oleh Joseph Von Hammer- Purgstall dalam sebuah artikel pada tahun 1851, ia mendefinisikan hadis tersebut sebagai "hadis yang suci atau surgawi" di mana .... Allah sendiri berbicara dan yang diwahyukan kepada nabi baik melalui Malaikat Jibril atau dalam mimpi”. Hanya beberapa tahun kemudian, dalam karya yang monumental Ensyclopaedia Islam (19131938) Arab-Inggris oleh Leksikon EW Lane, menyebutkan secara umum hadis Qudsi sama dengan “Hadis”.

Kamaruddin Amin, dalam karyanya "Menguji Kembali Keakuratan Metode Kritik Hadis", menjelaskan secara fakta yang berkaitan dengan kritik matan maupun sanad menyimpulkan bahwa sarjana hadis Muslim memberi perhatian paling besar pada jalur sanad dalam penilaiannya terhadap sebuah hadis, meskipun matan tidak diabaikan sama sekali. Namun demikian, matan hanyalah skunder (Kamaruddin, 2009: 60).

\section{Pemahaman Makna Al-Qur'an}

Al-Qur'an, menurut bahasa Arab merupakan kata yang diambil dari akar kata قرأ (membaca), namun kata tersebut diposisikan sebagai kata benda yang mempunyai kedudukan obyak, المقروء (yang dibaca). 
Menurut istilah agama, al-Qur'an adalah merupakan kalam Allah, yang bukan seperti kalam manusia yang kadang-kadang masih memerlukan kalimat dari sumbernya. Artinya bahwa untuk berbicara (kalam) diperlukan dua hal yang dapat memahamkan terhadap lawan bicara, yakni sebuah lafal yang diperkatakan dan sebuah alat bantu untuk berbicara yaitu lidah (al-lisan). Dengan alat bantu lisan ini, maka dapat mengeluarkan sebuah suara dengan huruf-huruf yang membentuk kaliamat dan dengan alat bantu itu dapat memahamkan lawan bicara yang tidak lagi memerlukan penjelasan. Berbeda dengan kalam yang kedatangannya melalui lubuk hati manusia yang sangat mendalam yang tidak memerlukan alat bantu seperti "panca indra", tetapi berbicara melalui kata-kata yang tersembunyi dalam benak pikirannya, sehingga apabila kata-kata itu di lafalkan dalam bentuk suara, maka hal itu disebut sebagai perkataan yang bersifat maknawiyah. Sebaliknya jika perkataan itu melalui lafal yang tersetruktur melalui benakan hati maka disebut sebgai perkataan yang bersifat nasfsiyah (AzZarqani, $1367 \mathrm{H}: 16$ ).

Pandangan ahli fikih dan ilmu kalam mengatakan bahwa Al-Qur'an adalah mempunyai dua konsep yang terdiri dari pengertian yang dapat disebut sebagai kalam maknawiyah dalam satu segi, dan dapat pula disebut kalam nafsiyah pada segi yang lain. Inilah pandangan antara para ulama uṣūl dan ulama fikih. Dimana ulama ușūl member konsep bahwa al-Qur’an secara umum berbicara tentang sifat-sifat Allah SWT sehingga dikatakan seperti mahluk pada umumnya. Sebaliknya al-Qur'an bukan sebuah hal yang mengandung sifat-sifat materi, tetapi kalam Allah karenanya alQur'an bukan sepert mahluk.

Menurut Fazlur Rahman (Fazlur Rahman, 1979: 30-31), wahyu adalah semacam ide yang masuk secara tiba-tiba ke dalam benak Muhammad. Ia hanya merupakan sebuah gagasan yang jelas, dan kemudian Nabi Muhammad menjadi "kepanjangan tangan" dari ide tersebut. Pemikiran Rahman yang demikian itu, sebagaimana dikemukakan di muka, tentu saja langsung mendapat kritikan tajam dari para penganut Islam yang telah mapan. Karena dalam pandangan tradisional, al-Qur'an adalah dari Allah, lafadz sekaligus maknanya. 


\section{Makna Turunnya (Nuzuul) Al-Qur'an}

Pentingnya pembahasan tentang makna turunnya al-Qur'an, bukan saja karena sebagai ilmu pengetahuan ansih, namun yang lebih penting lagi adalah sebagai dasar untuk mempertebal iman bagi umat Islam terhadap alQur'an yang merupakan kalam Ilahi, serta sebagai dasar untuk pembenaran tentang kenabian Muhammad sebagai Rasulullah.

Makna nuzūl al-Qur'an dari segi bahasa Arab diartikan alhulūl (lepas) dari satu tempat ketempat lainnya (Al-Manẓūr, tt: XI, 656).

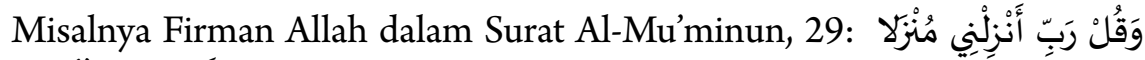
مُبَارَكا وَأَنْتَ خَيْرُ المْنْنِلِين (Dan berdoalah, "Ya Tuhanku, tempatkanlah aku pada tempat yang diberkahi, dan Engkau adalah sebaik-baik pemberi tempat.» Sedangkan makna nuzūl al-Qur'an secara umum adalah turun dari tempat di atas ke tempat di bawah atau berubahnya sesuatu dari tempat yang atas ke tempat yang bawah. Misalnya seseorang turun dari gunung. Dalam

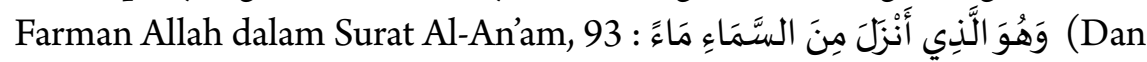
Kami turunkan (al-Qur'an itu dengan sebenar-benarnya dan al-Qur'an itu telah turun dengan (membawa) kebenaran.

Namun pengertian nuzūl dalam kontek turunnya al-Qur'an tidak bisa disamakan arti dengan pengertian nuzūl dalam kontek secara bahasa. Jika hal ini terjadi maka akan timbul pengertian bahwa al-Qur'an yang diturunkan kepada Muhammad adalah seolah-olah al-Qur'an turun dari atas yang mempunyai tempat seperti benda-benda lain yang bisa diturunkan kapan saja dan di tempat mana saja, dengan demikian al-Qur'an adalah mahluk yang sama seperti mahluk lainnya, yakni bersifat "baru" bukan bersifat "qadim" (dahulu). Ayat-ayat Al-Qur'an bukan demikian, karena ia mempunyai sifat, kandungan dan setatus wahyu dari Allah SWT yang bersifat asli dan kekal. Disini kata nuzūl juga mengandung arti yang bisa di takwilkan dengan kata i'lam yang berarti pemberitahuan atau pengajaran. maka nuzūlul Al-Qur'an beraati proses pembeitaan atau penyampaian ajaran Al-Qur'an yang terkandung didalamnya (Al-Zarqani: 41).

Menurut Jumhur ulama, antara lain Ar-razi (w.606 H), Imam Assuyuthi (w.911 H), Az-zarkasyi (w.794 H), dan lain-lain mengatakan : arti nuzūlul Qur'an itu secara hakiki tidak cocok untuk Al-Qur'an sebagai kalam Allah yang berada pada Dzat-Nya. Sebab dengan memakai ungkapan 
“diturunkan", menghendaki adanya materi kalimat atau lafal atau tulisan huruf yang riel yang harus diturukan. Karena itu arti kalimat "menetapkan/ memberitahukan/ memahamkan/ menyampaikan Al-Qur'an.” Baik disampaikan Al-Qur'an itu ke lauhul Mahfudh atau ke baitul izzah di langit dunia, maupun kepada nabi Muhammad SAW sendiri.

Sebagian ulama, antara lain Imam Ibnu Taimiyah mengatakan: Pengertian Nuzūlul Qur'an tu juga tidak perlu dialihkan dari arti hakiki kepada arti majazi.Maka kata Nuzūlul Qur'an itu berarti "turunnya Alquran "Sebab,arti tersebut sudah biasa digunakan dalam bahasa Arab (Ibnu Taimiyyah dkk, 2005: 257).

Menurut pandangan orientalis Barat, seperti H.A.R. Gibb AlQuran adalah kitab khutbah yang disampaikan oleh Muhammad secara lisan dalam kurun waktu kira-kira 20 tahun menjelang akhir hayatnya, Gibb sendiri berpendapat bahwa Al-Quran bukan berasal dari kumpulan kitab bibel ataupun yang lain. Namun begitu Gibb sendiri setuju dengan pendapat Ducan Black Mc Donald yang menyatakan bahwa bangsa arab sangat erat sekali hubungannya dengan pemikiran bangsa semit yanng suka menghubung-hubungkan keadaannya dengan hal-hal gaib, yang mereka caci sendiri dan lalu mereka pertahankan hubungan dengan halhal gaib tersebut (Gibb, 1990: 4).

Pemaknaan Al-Quran menurut Gibb, memang sudah menunjukan sebuah kemajuan berpikir dan kritis. Namun Gibb sendiri masih menafikan peran Allah yang harus lebih di utamakan dalam proses pembentukan wahyu dalam Al-Quran. Alquran bukan sekedar khutbah nabi Muhammad yang diterima nabi Muhammad dari Allah, namun al-quran maknanya lebih dari itu. Al-Quran merupakan pernyataan diri Tuhan kepada manusia dengan perantara nabi Muhammad sebagai utusan-Nya. Jadi Al-Quran bukan hanya sebagai kitab hukum saja, atau sekedar kitab sejarah para nabi-nabi Allah, Akan tetapi Al-Quran lebih kepada pembuktian diri Allah kepada manusia (Ibid).

\section{Perbedaan Al-Qur'an dan Hadis Qudsi}

Ada beberapa perbedaan antara al-Qur'an dengan hadis Qudsi, dan yang terpenting adalah sebagai berikut. 
1. Al-Qur'an adalah kalam Allah yang diwahyukan kepada Rasulullah saw. dengan lafal-Nya. Dan karena al-Qur'an sebagai wahyu Allah yang tidak ada seorangpun yang bisa menantang tentang kebesaran mu'jizatnya, tetapi mereka tidak mampu membuat seperti alQur'an itu. Tantangan itu tetap berlaku, karena al-Qur'an adalah mukjizat yang abadi hingga hari kiamat. Adapun hadis Qudsi tidak untuk menantang dan tidak pula untuk mukjizat. Firman Allah:

Dan jika kamu (tetap) dalam keraguan tentang Al Qur'an yang Kami wahyukan kepada hamba Kami (Muhammad), buatlah satu surat (saja) yang semisal Al Qur'an itu dan ajaklah penolong-penolongmu selain Allah, jika kamu orang-orang yang benar.(al-Baqarah:23).

2. Al-Qur'an hanya dinisbatkan kepada Allah, sehingga dikatakan Allah Taala berfirman. Adapun hadis Qudsi, seperti telah dijelaskan di atas, terkadang diriwayatkan dengan disandarkan kepada Allah, sehingga nisbah hadis Qudsi itu kepada Allah adalah nisbah dibuatkan. Maka dikatakan, Allah telah berfirman atau Allah berfirman. Dan, terkadang pula diriwayatkan dengan disandarkan kepada Rasulullah saw., tetapi nisbahnya adalah nisbah kabar, karena Nabi menyampaikan hadis itu dari Allah. Maka, dikatakan Rasulullah saw. mengatakan apa yang diriwayatkan dari Tuhannya. Seperti :

$$
\text { قال رسول الله صلي الله عليه وسلم فيما يرويه عن ربه عز وجل. }
$$

3. Seluruh isi al-Qur'an dinukil secara mutawatir, sehingga kepastiannya mutlak. Adapun hadis-hadis Qudsi kebanyakan adalah kabar ahad, sehingga kepastiannya masih merupakan dugaan. Adakalanya hadis itu sahih, hasan, dan daif.

4. Al-Qur'an dari Allah, baik lafal maupun maknanya. Hadis Qudsi (masih diperdebatkan oleh para ulama). Ada yang berpendapat maknanya dari Allah dan lafalnya dari Rasulullah saw. Hadis Qudsi ialah wahyu dalam makna, tetapi bukan dalam lafal. Oleh sebab itu, menurut sebagian besar ahli hadis, diperbolehkan meriwayatkan hadis Qudsi dengan maknanya saja. 
5. Membaca al-Qur'an merupakan ibadah, karena itu ia dibaca dalam salat.

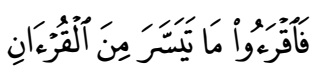

Maka, bacalah apa yang mudah bagimu dalam al-Qur'an itu." (AlMuzamil: 20).

6. Nilai ibadah membaca al-Qur'an juga terdapat dalam hadis, "Barang siapa membaca satu huruf dari al-Qur'an, dia akan memperoleh satu kebaikan. Dan, kebaikan itu akan dibalas sepuluh kali lipat. Aku tidak mengatakan alif laam miim itu satu huruf. Tetapi alif satu huruf, laam satu huruf, dan miim satu huruf." (HR Tirmizi dan Ibnu Mas'ud).Adapun hadis Qudsi tidak disuruh membacanya dalam salat. Allah memberikan pahala membaca hadis Qudsi secara umum saja. Maka, membaca hadis Qudsi tidak akan memperoleh pahala seperti yang disebutkan dalam hadis mengenai membaca alQur'an bahwa pada setiap huruf mendapatkan sepuluh kebaikan.

\section{Pemahaman Hadis Qudsi, dan Hadis Nabawi}

Hadis Qudsi adalah terdiri dari dua kata. Yakni, hadis dan Qudsi. Kemudian untuk memahami makna "hadis Qudsi", sementara kedua kata ini dimaknai secar terpisah. "Hadis" dimaknai segala sesuatu yang baru, atau sesuatu yang sebelumnya tidak ada, peristiwa, berita, ceritera, menyampaikan sesuatu risalah, peristiwa kenabian yang datang dari Allah (Ibnu Manzur:131). Kemudian kata "Qudsi” dimaknai suci. bersih, sifat kesucian Allah. Namun jika kata "Qudsi” dirangkai dengan kata lain, maka akan mempunyai makna lain. Seperti, kata "Haḍiratul Qudsi” atau Jannatul Qudsi” diartikan "surga”, dan "Ruh al-Qudus" diartikan Malaikat Jibril (Ibid: 168).

Jika kata hadis dan Qudsi digabung menjadi satu yaitu, "hadis Qudsi”, maka akan para ulama hadis mempunyai pengertian dalam berbagai pandangan antara lain:

- Imam al-Bukhari (194 H-256 H) dalam “al-jāmi' al-Sahîh" memberikan definisi bahwa hadis Qudsi ialah, Hadis yang diriwayatkan oleh Nabi dar Tuhannya, dengan disampaikan secara makna dan secara lafal dari Allah 'Azza waJalla (Badruddin, 
2006: 235). Pandangan ini dibuktikan pada hadis-hadis Qudsi yang tercantum dalam kitab al-Bukhari dalam bab tentang firman Tuhan. Misalnya:

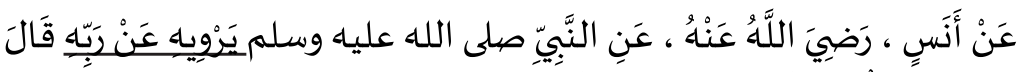

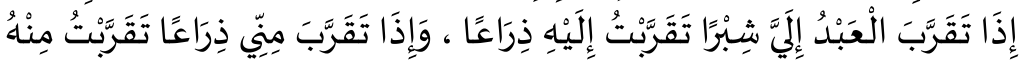

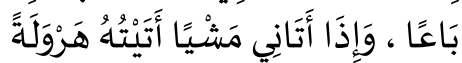

Dari Anas Radliyallahu>anhu, dari Nabi saw, meriwayatkan dari Tuhannya, Allah berfirman: «Jika seorang hamba mendekatkan diri kepada-Ku sejengkal, maka Aku akan mendekat kepadanya sehasta, jika ia mendekatkan diri kepada-Ku sehasta maka Aku mendekat kepadanya sedepa, dan jika ia mendekatkan diri kepada-Ku dengan berjalan maka Aku akan mendatanginya dengan berlari.» (H.R. Al-Bukhari).

- Al-Jurjani (1339-1414) dalam karyanya, "al-Tárifät" mendefinisikan bahwa hadis Qudsi adalah hadis yang secara makna datang dari Allah, sementara redaksinya dari Rasulullah saw. Sehingga hadis Qudsi adalah berita dari Allah kepada Nabi-Nya melalui ilham atau mimpi, kemudian Rasulullah saw, menyampaikan hal itu dengan ungkapan beliau sendiri. Untuk itu, al-Al-Qur'an lebih utama dibanding hadis qudsi, karena Allah juga menurunkan redaksinya (Al-Jurjani, $1405 \mathrm{H}: 113$ ).

- Al-Munawi (1545 - 1622) dalam karyanya” Faidul Qadir Syarh alJami' al-Sahir memberikan pengertian hadis Qudsi ialah, berita yang Allah sampaikan kepada Nabi-Nya saw secara makna dalam bentuk ilham atau mimpi. Kemudian Nabi saw menyampaikan berita 'makna' itu dengan redaksi beliau (Abdurrauf dkk, 1994: 468).

- Kata al-Tỉbiy, keutamaan al-Qur'an atas hadis Qudsi adalah karena hadis Qudsi merupakan teks dari Tuhan yang mempunyai derajat kedua, sekalipun keberadaannya secara umum adalah bukan melalui perantara Malaikat, karena dipandang pada sisi maknanya bukan lafalnya. Berbeda dengan al-Qur'an yang lafal dan maknanya dari Tuhan, karena itu hadis Nabi pada umumnya diposisikan pada tingkatan terakhir.

Sementara menurut Ibnu Hajar, dalam kitab "Ta'rif ahli al-Taqdīs" hadis Qudsi merupakan hadis yang dikategorikan sebagai hadis-hadis 
Ilahiyah (Ketuhanan). Karena itu hadis Qudsi kemungkinannya diambil oleh Nabi dari Allah Swt. dengan melalui perantara atau tidak (Ibid: 615).

Menurut az-Zarqani (w,1122 H), hadis Qudsi yang disampaikan Rasulullah saw, adalah merupakan sebuah ceritera dari Allah SWT atau kalam Allah. Namun hadis Qudsi tidak memiliki keistimewaan khusus seperti halnya al-Al-Qur'an (Az-Zarqani: 50). Demikian pula hikmah Allah membedakan kalam-Nya dengan sifatnya yang mukjizat dan tidak mukjizat, adalah untuk membedakan tentang kebolehan meriwayatkan dengan makna atau tidak, dan secara psikologis kebolehan atau tidak membawa, dan memegangnya secara bebas. Disamping sebagai pembeda keduanya adalah ketika al-Qur'an diperbolehkan menyampaikan secara makna tanpa diikuti dengan lafal-lafal yang baku, maka akan hilang nilai-nilai kemukjizatan al-Qur'an. Sehingga al-Qur'an akan mengalami perubahan, pergantian serta perbedaan kalimat yang dapat merubah setruktur ayat dan surat sesuai dengan kehendaknya, dan yang paling membahayakan lagi adanya perbedaan hukum-hukum yang terkandung di dalamnya. Berbeda denngan hadis Qudsi atapun hadis Nabi pada umumnya, lafallafal keduanya tidak menandung keistimewaan (mukjizat), karena itulah kebolehan keduanya diriwayatkan secara makna. Bahkan keistimewaan dan kesucian al-Qur'an tidak boleh disandangkan pada hadis Qudsi dan hadis Nabi pada umumnya (Ibid: 37-38).

Menurut Fatwa Syaih Muhammad bin Șalih al-Aṣiminn (1929 2001) yang menyatakan bahwa para ulama telah berbeda pendapatnya dalam memberikan pengertian hadis Qudsi. Apakah hadis Qudsi itu kalam Allah atau apakah Allah Ta'ala mewahyukan kepada Rasul-Nya dengan secara makna, sedangkan lafalnya dari Rasulullah saw sendiri?. Dalam hal ini ada dua pendapat:

Pertama, bahwa Hadsis Qudsi lafal dan maknanya dari Allah Ta’ala. Dikatakan demikian, alasannya karena Rasulullah saw meriwayatkan dengan dsandarkan kepada Allah SWT, serta diketahui bahwa asalusul ucapan itu karena sumbernya disandarkan pada lafal orang yang mengucapkan, bukan pada pemindahannya. Lebih-lebih orang yang mengucapkan adalah seorang Rasul yang sebaik-baik manusia, baik dari segi tingkat kepercayaannya maupun segi keadilannya. 
Kedua, bahwa hadis Qudsi merupakan hadis yang maknanya dari Allah SWT, tetapi lafalnya dari Nabi saw. Ibnu al-Așīmin dalam fatwanya mengatakan, jika perbedaan pendapat yang pertama tidak lagi dibahasnya dalam persoalan ini, karena dikhawatirkan dikatakan sebagai pendapat yang ekstrim dan membinasakan, maka cukup berpendapat bahwa hadis Qudsi adalah hadis yang diriwayatkan Nabi dari Tuhannya. Demikian cukup aman, jelas dan singkat (Al-Asīimi, 2001: 69).

Sementara dari dua pendapat yang berbeda dalam maslah ini, yang banyak diterima oleh kalangan orang-orang yang berpengetahuan mengatakan, bahwa hadis Qudsi adalah hadis yang lafal dan maknanya diwahyukan oleh Allah SWT.

Menurut Syaih Abdul 'Aziz al-Rājikhi (L.1941 M.) mengatakan bahwa, hadis Qusi adalah kalam Allah dari segi lafal dan maknanya, demikian pula al-Qur'an. Tetapi yang membedakannya adalah pada segi hukum dan kekhususannya. Jika al-Qur'an dipegang oleh seseorang yang mengharuskan berwuḍu dan yang membacanya mendapatkan pahala, sementara hadis Qudsi tidak demikian.

Pendapat Syaih Șaleh bin Fauzan bin Abdullah (L. 1933 M.) dalam karyanya " al-Diya' al-lami' " mengatakan, hadis Qudsi ialah hadishadis yang diriwayatkan oleh Nabi saw., dari Tuhan 'Azza wa Jalla., secara lafal dan makna, dan ia merupakan bagian dari sunah Nabi yang suci, yang mempunyai keistimewaan yang disandarkan kepada Allah SWT. Karenanya Allah berbicara dan mewahyukan kepada Rasulullah saw untuk menyampaikan kepada umatnya. Berbeda dengan hadis Nabi pada umumnya yaitu, lafalnya merupakan kalam Rasulullah sedangkan maknanya dari Allah SWT., alasanya bahwa sunah Nabi semuanya adalah sebagai wahyu......Tetapi ada sesuatu perkataan yang datang dari Rasulullah saw dengan secara lafal dan maknanya, maka disebut sebagai hadis Qudsi, dan ada sesuatu perkataan Nabi yang maknanya dari Allah tanpa dengan lafalnya, maka disebut sebagai hadis Nabi secara umum.

Pandangan ini sedikit mempersoalkan terhadap kandungan hadis qudsi yang sering mempergunakan perkataan: ياعبادي، يابن ادم . Katakata ini sedikit mengganjal dalam pikirannya yang seolah-olah masih ada kaitannya dengan penyandaran Nabi dengan Tuhan, yakni sandaran perkataan yang tidak langsung. 
Adapun yang dimaksud dengan hadis nabawi adalah hadis Nabi yang disandarkan secara keseluruhan kepada Nabi baik makna maupun lafalnya dengan bentuk ucapan, perbuatan, taqrir dan sifat-sifatnya.

Ada dua sifat yang terkandung dalam hadis Nabawi yaitu:

Pertama, Tauqifi yaitu yang kandungannya diterima oleh Rasulullah SAW dari wahyu, lalu ia menjelaskan kepada manusia dengan kata-katanya sendiri. Bagian ini, meskipun kandungannya dinisbahkan kepada Allah, tetapi dari segi pembicaraan lebih dinisbahkan kepada Rasulullah SAW, sebab kata-kata itu dinisbahkan kepada yang mengatakannya, meskipun di dalamnya terdapat makna yang diterima dari pihak lain.

Kedua, Taufiqi yaitu: yang disimpulkan oleh Rasulullah SAW menurut pemahamannya terhadap Quran, karena ia mempunyai tugas menjelaskan Quran atau menyimpulkannya dengan pertimbangan dan ijtihad. Bagian kesimpulannyang bersifat ijtihad ini, diperkuat oleh wahyu jika ia benar, dan jika terdapat kesalahan didalamnya, maka turunlah wahyu yang membetulkannya. Bagian ini bukanlah kalam Allah secara pasti.

Dari sini jelaslah bahwa hadis nabawi dengan kedua bagiannya yang tauqifi dan taufiqi dengan ijtihad yang diakui oleh wahyu itu bersumber dari wahyu. Dan inilah makna dari firman Allah tentang Rasul Muhammad saw.

$$
\text { وَمَا يَنْطِقُ عَنِ الْهَوَى ، إِنْ هوَ إلَّاَّ وَخْيَ يُوحَى }
$$

Dan tiadalah yang diucapkannya itu menurut kemauan hwa nfsu nya. Ucapannya itu tiada lain hanyalah wahyu yang diwahyukan (An-Njm: 3-4)

\section{Klasifikasi Hadis Qudsi dan Hadis Nabawi}

Para ulama hadis telah mengklasifikasikan hadis ke dalam berbagai tinjauan sesuai dengan sifat, bentuk, jumlah, kualitas dan kehujahan sebuah hadis. Tinjauan mereka, berlaku umum baik terhadap hadis nabawi maupun pada hadis Qudsi. Karena itu jika di dalam hadis Nabi banyak dilakukan kritik, baik kritik pada sanad maupun matan, maka terjadi pula terhadap hadis Qudsi. Jika para ulam hadis telah melakukan penelitian hadis dengan berdasarkan ilmu pengetahuan hadis yang mereka kuasai, kemudian menghasilkan klasifikasi hadis Sahih, Hasan dan Da'if, maka terjadi pula pengklasifikasian terhadap hadis-hadis Qudsi. Misalnya, hadis 
Qudsi ada yang mempunyai tingkatan sanad marfu', mauquf dan maqtu'. Dan terdapat pula hadis Qudsi yang sahih dan ada pula yang ḍa'if.

Kitab kumpulan hadis-hadis Qudsi memang banyak ada yang tersusun dengan bahasa Arab dan dan ada pula dengan bahasa terjemah. Salah satu kitab hadis Qudsi dalam bentuk asli tulisan Arab, diantaranya kitab yang paling masyhur mengenai Hadîts Qudsiy adalah kitab الاتحافات السنية بالأحاديث القدسية (al-Ithâfât as-Saniyyah Bi al-Ahâdîts al-Qudsiyyah) karya 'Abdur Ra' uf al-Munawiy (w. 1035 H.). Di dalam buku ini terkoleksi 272 buah hadits. Menurut pengarag karya tersebut mengatakan bahwa hadis Qudsi yang terdapat dalam koleksi susunannya, belum dipisahkan antara hadis-hadis Qudsi yang sahih maupun yang da'if. Kemudian oleh seorang pensyarah Muhammmad Munir bin 'Abduh al-Damsyiqy, sedikit meberikan penjelasan asal usul hadis dan setatusnya. Metode yang digunakan dalam penulisan hadis Qudsi, dan agar mudah bagi para pencari hadis Qusdsi didapat dengan cepat, maka oleh Syaih al-Manawi ditulis dengan menggunakan metode penulisan menurut abjad Hijaiyah (Al-Manawi, 1994: 8).

Karena hadis Qudsi itu terbilang jumlahnya sedikit, tidak seperti halnya hadis-hadis Nabawi, maka dalam susunanya-pun tidak sebanyak yang tersusun seperti hadis-hadis Nabawi. Jika kita melihat hadis-hadis Nabawi yang tersusun dalam kitab-kitab hadis maka dapat terlihat secara jelas susunan dan kandungan hadis-hadis itu secara teratur. Ada susunan kitab yang berdasarkan indek kitab-kitab fikih (hukum). Seperti kitab al-Muwața karya imam Malik bin Anas (w. 179 H.), ada juga kitab hadis yang tersusun berdasarkan klasifikasi sanad-sanad (musnad) hadis. Seperti Musnad Akhmad bin Hanbal.

Ciri pada hadis Qudsi, biasanya menggunakan kalimat-kalimat seperti:

- Rasulullah saw, menyampaikan sabdanya dengan cara menyandarkan kepada Tuhan atau "mengatasnamakan Tuhan". Misalnya:

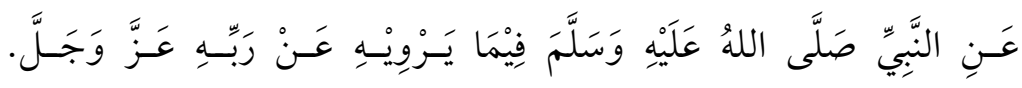


- Firman Tuhan yang diriwayatkan oleh Rasulullah dengan tidak langsung. Misalnya:

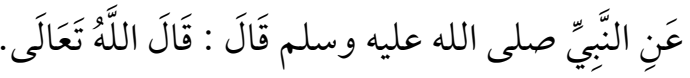

- Firman Tuhan yang diperkuat dengan berperannya malaikat Jibril. Misalnya:

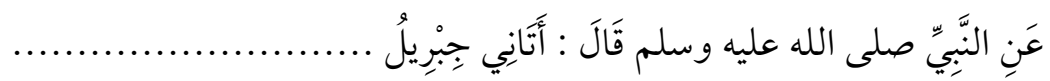

- Hadis Qudsi sering diawali dengan perkataan ياادم ، يا ابن ادم atau Misalnya:

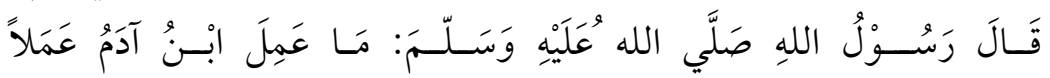

- Hadis Qudsi biasanya diawali dengan memakai kata pemanggilan pada seorang hamba, يا عبادي. Misalnya:

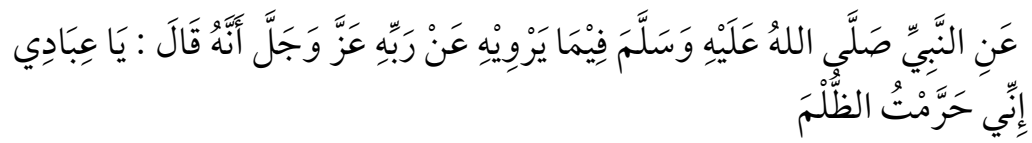

\section{Analisis Pemahaman Pemaknaan Hadis Qudsi.}

Hadis Qudsi memang jumlahnya tidak sebanyak hadis Nabi pada umumnya. Hadis Qudsi tersebar diberbagai kitab hadis, termasuk ada sebagian yang ditulis dalam kitab al-Bukhari. Dan Imam Bukhari memasukan hadis Qudsi dalam kitabnya, tidak dikelompokkan pada kitab (Bab) tersendiri. Tetapi ditulis di berbagai bab dan masuk pada bagianbagiannya. Pada kumpulan atau koleksi hadis-hadis Qudsi yang dihimpun diberbagai buku kumpulan hadis Qudsi, ada yang mengatakan Jumlahnya lebih sedikit dari 200 hadits.

Di antara buku yang paling masyhur mengenai hadis Qudsi adalah kitab "Al-Itthâfât as-Suniyyah bi al-Ahâdîts al-Qudsiyyah" karya "Abdur Ra' uf al-Munawiy. Di dalam buku ini terkoleksi 272 buah hadits. Karena hadis Qudsi sebenarnya adalah untuk Muhammad sebagai pribadi Nabi, bukan sebagai Rosul, maka Nabi pun "pilih-pilih" dalam memberikannya kepada sahabat - sahabatnya . Hanya sahabat - sahabat terpilih yang mempunyai kecerdasan tinggi saja yang menerimanya. Karena memang 
hadis Qudsi bukan untuk konsumsi umum. Sampai sekarang pun masih sebagian kalangan umat Islam yang belum menerima "kebenaran" Hadis Qudsi. Para periwayatpun jumlahnya sangat terbatas, hanya sahabat sahabat khusus saja yang menerima hadis Qudsi dari Nabi Muhammad, semisal Sayyidina Ali bin Abu Tholib dan sahabat Abu Hurairah, Anas bin Malik dan 'Aisyah.

Pemaknaan hadis Qudsi para ulama sangat beragam dalam menjelaskan pengertiannya baik oleh ulama salaf (koservatif) maupun khalaf (moderen), sebagaimna kami jelaskan di muka. Maka paling tidak dapat kami petakan dalam empat pengertian yaitu:

Pertama, pandangan yang diwakili oleh kebanyakan ulama koservatif misalnya; Ibnu Hajar, imam Bukari, Al-Jurjani, Al-Munawi, al-Tîibiy. Mereka menjelaskan hadis Qudsi yaitu, berita dari Allah yang disampaikan kepada Nabi saw secara makna, dan lafalnya disampaiakn oleh Nabi sendiri.

Kedua, pandangan dari kalangan para ulama koservatif seperti, azZarqani hadis Qudsi, adalah merupakan sebuah kalam atau ceritera dari Allah SWT yang disampaikan Rasulullah saw. Namun hadis Qudsi tidak seperti al-Quran yang memiliki keistimewaan-keistimewaan. Jadi hadis Qudsi hampir disandingkan perbedaannya dengan al-Qur'an.

Ketiga, pendapat yang diwakili oleh para ulama salaf moderen seperti, Syaih Muhammad bin Șalih al-Așīmīn, menyatakan sebaiknya hadis Qudsi sudah tidak lagi dibahasnya, karena dikhawatirkan dikatakan sebagai pendapat yang ekstrim dan membinasakan, maka cukup berpendapat bahwa hadis Qudsi adalah hadis yang diriwayatkan Nabi dari Tuhannya. Jadi pendapat ini boleh jadi dikatakan sebagai pendapat yang tidak mengambil resiko daripada dituduh bertentangan dengan pendapat pendahulunya (ahli salaf).

Keempat, pendapat salaf modern yang sedikit berbeda dengan para pendahulunya. Yaitu pandangan yang disampaikan oleh seorang Mufti Syaih Șaleh bin Fauzan bin Abdullah, bahwa sunah Nabi semuanya adalah sebagai wahyu.....Tetapi ada sesuatu perkataan yang datang dari Rasulullah saw dengan secara lafal dan maknanya, maka disebut sebagai hadis Qudsi, 
dan ada sesuatu perkataan Nabi yang maknanya dari Allah tanpa dengan lafalnya, maka disebut sebagai hadis Nabi secara umum.

Pandangan ini sedikit mempersoalkan terhadap kandungan hadis qudsi yang sering mempergunakan perkataan: ياعبادي، يابن ادم . Katakata ini sedikit mengganjal dalam pikirannya yang seolah-olah masih ada kaitannya dengan penyandaran Nabi dengan Tuhan, yakni sandaran perkataan yang tidak langsung.

Melihat dari pemetaan terhadap definisi hadis Qudsi ini, kami sependapat dengan pandangan Syaih Șaleh bin Fauzan bin Abdullah (http://www.alfawzan.af.org.sa, 2014) bahwa, hadis Qudsi adalah, suatu hadis yang khusus tetapi jelas merupakan hadis yang diverbalkan oleh Nabi secara keseluruhan baik makna maupun lafalnya. Oleh karena itu, hadis Qudsi sama halnya dengan hadis Nabi pada umumnya, tidak ada perbedaan dengan hadis Nabawi. Apabila hadis nabawi terdapat klasifikasi hadis sahih, hasan dan dạ'if, maka demikian juga pada hadis Qudsi. Hanya ada beberapa perbedaan yang berkenaan dengan materi hadis Qudsi, dimana hadis Qudsi tidak lebih luas daripada hadis Nabawi. Hadis Qudsi merupakan hadis yang hanya mengatasnamakan Tuhan (Allah SWT) saja. Karenanya hadis Qudsi bukan firman Tuhan secara langsung, tetapi diverbalkan lafal dan maknany dari nabi sendiri.

Adapun yang perlu dikupas lebih lanjut dalam persoalan hadis Qudsi adalah keberadaan kata-kata: ياعبادي ، يابن ادم, yakni sebagai katakata yang masih ada kaitannya dengan penyandaran Nabi dengan Tuhan, yakni sandaran perkataan yang tidak langsung, tanpa menyebut subyek secara jelas dan bersifat umum.

Hal demikian, dapat dijelaskan bahwa Nabi Muhammad saw, telah diutus oleh Allah dengan segala keistimewaan dan kelebihan dibandingkan denga Nabi dan Rasul sebelumnya. Sehingga sangat mungkin keistimewaan tersebut ada pada diri seorang Nabi Muhammad saw. Untuk itu disini dapat dijelaskan beberapa alasan:

a. Nabi Muhammad saw. sebagai hamba yang istimewa dan terpilih oleh Allah dari hamba-hamba yang lainnya (kholilullah).

Nabi bersabda: 


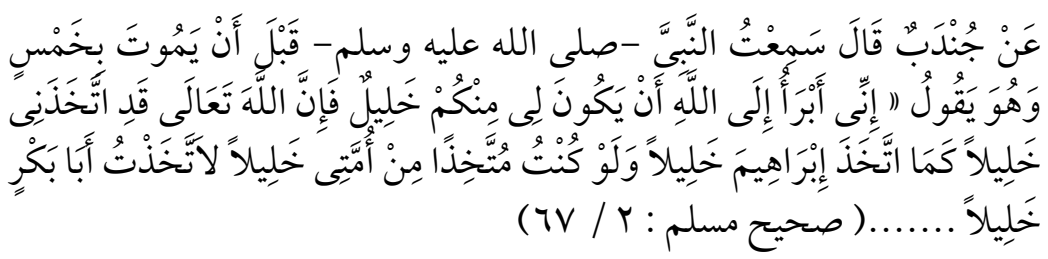

Dari Jundab bin Abdillah Ra, beliau berkata: "Aku telah mendengar Nabi Muhammad saw, lima hari sebelum meninggal, beliau bersabda: "Sesungguhnya aku berlepas diri kepada Allah, untuk menjadikan dari kalian untukku sebagai kekasih (Kholil) karena sesungguhnya Allah telah menjadikanku sebagai kekasih-Nya sebagaimana Allah menjadikan Ibrahim juga kekasih-Nya, jikalau aku menjadikan dari umatku seorang kekasih nisaya aku jadikan Abu Bakar sebagai kekasih.... (HR. Muslim).

Kata imam Muslim bahwa menurut al-Nuhas, kata "al-khalil" dalam hadis ini dimaksudkan adalah kekhususan pada sesuatu yang lainnya, Namun bagi Rasul tidak diperkenankan memilah-milah sesuatu agama dalam dakwahnya. Sebagaimana Firman Allah: "Hai Rasul, sampaikan apa yang diturunkan kepadamu dari Tuhan-mu” (QS. Al-Maidah: 5).

Dan lebih lanjut menurutnya bahwa "al-Khalil" diartikan sebagai sesuatu kebutuhan atau keinginan yang sangat mendesak. Atau dikatakan oleh Qạ̣i 'Iyaḍ (w. $544 \mathrm{H}$ ) yaitu sebagai kasih sayang yang tumbuh dalam hati, atau sifat-sifat kerinduan. Bagi Nabi saw sifat kerinduan dalam hatinya sangat butuh bukan terhadap sesorang mahluk tetapi kebutuhan keriduan terhadap Tuhannya (Al-Qadi 'Iyad: 252).

Kasih sayang seorang hamba terhadap Tuhannya dan atau Tuhan kepada hamba yang dipilih-Nya, adalah mempunyai implikasi yang mendalam terhadap kedua belah pihak. Allah SWT, memilih Muhammad sebagai seorang Nabi, tentu apa yang diperbuat atau dirancang oleh Nabi tidaklah pernah meragukan kebenaran dan keadilannya, sehingga Allah tanpa ragu pula menyerahkan semua segala apa yang akan diperbuatnya. Apabila Nabi membuat sebuah hadis Qudsi yang berisikan pesan-pesan moral yang berkaitan dengan kehidupan manusia dengan mengatasnamakan Tuhannya, maka akan dipastikan Allh SWT akan rela (rị̣a) dan menyetujuai segala apa yang akan diperbuat oleh Nabi saw.

Secara logika dapat dicontohkan, ketika seseorang yang ditunjuk untuk menjadi seorang pemimpin (presiden, raja, khalifah), maka dalam tugas kesehariannya tidak bisa dilaksanakan dengan sendirian, tetapi 
pasti harus ada orang lain yang bisa membantu atau bekerja sama. Maka ia di dalam melaksanakan tugas tersebut tidak lain untuk membantu demi seorang pemimpinnya, dan tentu ia bekerja bukan saja didasarkan untuk dirinya tetapi untuk atas nama pemimpinnya. Demikian halnya Nabi Muhammad saw, seorang Rasulullah (utusan Tuhan), serta sebagai khalifah di bumi (khalifatan fil ardii). Tentu beliau diperintahkan Tuhan untuk membuat statemen-statemen yang berkenaan dengan agama (moral) adalah bukan untuk atas nama dirinya, tetapi atas nama Tuhan yang mengutus-Nya.

Adapun persoalan dari beberapa hadis Qudsi, yang disampaikan Nabi saw, dengan menggunakan kata-kata ياعبادي ، يابن ادم adalah bukan menjadi sebuah persoalan dalam pikiran seseorang yang memaknai hadis Qudsi lafal dan maknya dari Nabi sendiri. Tetapi memang hal itu bisa menjadi persoalan dalam pikirannya ketika hadis Qudsi masih tetap didefinisikan sebagai hadis yang maknanya dari Tuhan dan lafalnya dari Nabi. Namun ketika pikiran itu dikembalikan pada penjelasan di atas yaitu, Nabi saw sebagai seorang khalilullah, maka apapun yang diperbuat Nabi saw, tidak akan menjadi halangan dalam alam pikiran seseorang termasuk di dalam penggunaan kata-kata: ياعبادي ، يابن ادم.

\section{b. Nabi Muhammad saw, memiliki kedudukan yang terpuji (Al Maqom Al Mahmudah)}

Seorang Nabi yang berkedudukan tinggi karena memang telah ditempatkan oleh Allah SWT pada posisinya yang sangat tinggi dan terhormat. Sebagaimana Firman Allah dalam QS. Al Isra': 79: عَسَى أَنْ يَبْعَثَكَ رَبُكَكَ مَقَامًا مَحْمُمدًَا (Mudah-mudahan Tuhan-mu mengangkat kamu ke tempat yang terpuji).

Seorang Nabi yang diberi peringkat terpuji dihadapan Tuhan, tentu bagi Allah sudah tidak ada lagi batasan sehingga apa yang menjadi segala perbuatan dan perencanaanya tidak perlu lagi adanya batasan pula. Maka ketika Nabi bersabda dengan hadis Qudsi dengan mengatasnamakan Tuhannya, maka Allah SWT-pun akan rela (rida) apa yang disabdakan, karena Nabi saw dengan sifat dan perbuatannya telah terpuji. 


\section{Simpulan}

Bertumpu pada pemasalahan dan penjelasan di atas dapat disimpulkan bahwa hadis Qudsi jumlahnya tidak sebanyak hadis Nabi pada umumnya. Hadis Qudsi terdapat diberbagai kitab hadis, termasuk ada sebagian yang ditulis dalam kitab al-Bukhari. Imam Bukhari memasukan hadis Qudsi dalam kitabnya, tidak dikelompokkan pada satu kitab (bab) tersendiri. Tetapi ditulis di berbagai bab dan masuk pada bagian-bagiannya. Di antara buku yang paling masyhur mengenai Hadits Qudsi adalah kitab "Al-Ittihâfât as-Suniyyah bi al-Ahâdîts al-Qudsiyyah" karya 'Abdur Ra 'uf alMunawiy. Kitab ini terdapat sekitar 7 hadis Qudsi yang diriwayatkan oleh al-Bukhari dalam kitab al-jami'u as-Ṣahīhnya dan terdapat 14 hadis yang diulang-ulang serta diberi syarah dan dimasukan karena ada kesamaan maksud dan pengertiannya. Dalam kitab al-jami'u as-Ṣahīh al-Bukhari juga tidak membedakan mana hadis yang Qudsi dan mana yang hadis Nabi pada umumnya. Hanya saja yang dapat membedakan adalah dari segi lafallafal. Misalnya, kata-kata, قال تعالي ، يا عبادي ، dan lainnya.

Para ulama dalam menjelaskan perbedaan al-Qur'an dengan hadis Qudsi, mereka masing-masing mempunyai pandangan yang berbeda dalam merinci banyak dan sedikitnya. Namun mereka tetap menonjolkan keistimewaan al-Qur'an daripada hadis Qudsi. Lebih-lebih penonjolan itu pada konsep pewahyuan al-Qur'an yang digambarkan bahwa al-Qur'an disampaikan kepada Nabi melalui dua konsep metodologi. Pertama, melalui konsep metodologi internal, yaitu pewahyuan yang digambarkan Abduh, sebagai pengetahuan yang didapatkan seseorang dari dalam dirinya dengan keyakinan bahwa itu datangnya dari Allah, baik dengan perantara maupun tanpa perantara tanpa suara. Dan kedua, konsep metodologi eksternal yang memposisikan al-Qur'an sebagai wahyu Tuhan yang telah berubah menjadi teks manusiawi sejak pertama kali turun kepada Nabi Muhammad saw. Karena jika tidak demikian, maka Kalam Ilahi tersebut tidak akan dimengerti.

Pemaknaan hadis Qudsi para ulama sangat beragam dalam menjelaskan pengertiannya baik oleh ulama salaf (koservatif) maupun khalaf (moderen). Maka paling tidak dapat dipetakan dalam empat pengertian yaitu: 
Pertama, pandangan yang diwakili oleh kebanyakan ulama koservatif misalnya; Ibnu Hajar, imam Bukari, Al-Jurjani, Al-Munawi, al-Tîbiy. Mereka menjelaskan hadis Qudsi yaitu, berita dari Allah yang disampaikan kepada Nabi saw secara makna, dan lafalnya disampaiakn oleh Nabi sendiri. Kedua, pandangan dari kalangan para ulama koservatif seperti, az-Zarqani hadis Qudsi, adalah merupakan sebuah kalam atau ceritera dari Allah SWT yang disampaikan Rasulullah saw. Namun hadis Qudsi tidak seperti al-Qur'an yang memiliki keistimewaan-keistimewaan. Jadi hadis Qudsi hampir disandingkan perbedaannya dengan al-Qur'an. Ketiga, pendapat yang diwakili oleh para ulama salaf moderen seperti, Syaih Muhammad bin Șalih al-Aṣīmīn, menyatakan sebaiknya hadis Qudsi sudah tidak lagi dibahasnya, karena dikhawatirkan dikatakan sebagai pendapat yang ekstrim dan membinasakan, maka cukup berpendapat bahwa hadis Qudsi adalah hadis yang diriwayatkan Nabi dari Tuhannya. Jadi pendapat ini boleh jadi dikatakan sebagai pendapat yang tidak mengambil resiko daripada dituduh bertentangan dengan pendapat pendahulunya (ahli salaf). Keempat, pendapat salaf modern yang sedikit berbeda dengan para pendahulunya. Yaitu pandangan yang disampaikan oleh seorang Mufti Syaih Șaleh bin Fauzan bin Abdullah, bahwa sunah Nabi semuanya adalah sebagai wahyu.....Tetapi ada sesuatu perkataan yang datang dari Rasulullah saw dengan secara lafal dan maknanya, maka disebut sebagai hadis Qudsi, dan ada sesuatu perkataan Nabi yang maknanya dari Allah tanpa dengan lafalnya, maka disebut sebagai hadis Nabi.

Dari pemetaan terhadap definisi hadis Qudsi ini, Penulis sependapat dengan ulama hadits yang mengatakan bahwa, hadis qudsi suatu hadis yang khusus tetapi merupakan hadis yang diverbalkan oleh Nabi secara keseluruhan baik makna maupun lafalnya. Oleh karena itu, hadis Qudsi sama halnya dengan hadis Nabi pada umumnya, tidak ada pula perbedaannya dengan hadis Nabawi. Apabila hadis nabawi terdapat klasifikasi hadis sahih, hasan dan da’if, maka demikian juga pada hadis Qudsi. Hanya ada beberapa perbedaan yang berkenaan dengan materi hadis Qudsi, dimana hadis Qudsi tidak lebih luas daripada hadis Nabawi. Hadis Qudsi merupakan hadis yang hanya mengatasnamakan Tuhan (Allah SWT) saja. Karenanya hadis Qudsi bukan firman Tuhan secara langsung, tetapi diverbalkan lafal dan maknany dari nabi sendiri. 


\section{BIBLIOGRAFI}

Abu Hamim al-Ghazali, Al-Munqidz min al-Dlalal, (Cairo: Silsilah Tsaqafat Islamiyah, 1961).

Abul Husain Muslim bin Hajaj, al-jāmi' al-Sahịh, (Bairut: Dār Jail, $1334 \mathrm{H})$.

Abu Ja'far At-Tabari, Jāmi' al-Bayaān fī Ta'wīl al-Qur;an, Muassasah alRisālah, 2000.

Al-Bukāri, Muhammad bin Ismail. al-Jāmi' as-Ṣahihal-Mukhtaṣar, (Bairut: Dār Ibn Katsir, 1987).

Al-Asīmi, Muhammad bin Salih bin Muhammad, Majmu' Fatāwa wa Rasāil, (Dār al-Wațan, 2001).

Al'Aini, Badruddin, Umdatul Qari Syarh Saḥiḥ al-Bukhari, (Multaqa ahli al-Hadis, 2006).

Al-Albani, Muhammad Nasiruddin, Da'iffal-Tarhīb wa al-Tarhīb, (Riyad: Maktabah al-Ma'arif, tt). , Sahih wa Da'if al-Jami; al-Sahìr, (Iskandaria: Markaz Nur alIslam, $\mathrm{tt})$.

Al-Asqalani, Abu al-Fadl Ahmad bin 'Ali bin Muhammad bin Hajar, (Yordan: Ta'rif ahli al-Taqdīs, Maktabah al-Manār, tth.). , Fathul Bariy Syarah Sahih al-Bukhariy, (Bairut: Dâr al-Ma'arif, tth.).

Al-Jurjani, 'Ali bin Muhammad bin 'Ali, al-Ta'rifät, Bairut, (tt.: Dār al-Kitab al-Arabi, $1379 \mathrm{H}$ ).

Al-Qadi 'Iyad, Ikmāl al-Mu'allim Syrh Shih Muslim, (tt., tp., tth.).

Al-Manawi, Muhammad Abdur Rauf, Faidul Qadir Syarh al-Jami' al-Sahīr, (Cet I, Bairut, Dār al-Kutub al-Ilmiyyah, 1994).

Andrew Rippin, “The Function of Asbab an-Nuzul Qur'anic Exegesis”, dalam Jurnal Studi al-Quran, Vol, I, No. 2, 2006 
As-Syafî̀ i, Abi Abdillah Muhammad bin Idris, al-Um, (Bairut: Dār al-Fîkri, 1983). 'Ilmiayyah,1986).

Ikhtilaf al-Hadis, (Bairut: Dār al-Kutub al-

As-Ṣan’aniy, Abi Muhammadbin Isma'il bin Salah, Tadih al-Afkâr li ma'ani Tanqih al-Anżar, (Birut: Dâr al-Kutub al-'Ilmiyah, 1997).

Az-Zarqani, Muhammad Abdul 'Aẓim, (tt: Mnāhil al'Irfān fì ‘Ulūm al-Qur'an, Matba'ah 'Isa al-Bābi al-Halabi, tth.)..

'Itr, Nur Ad-Din, Manhaj An-Naqd fî̀ 'Ulum al-Hadis, (Damaskus, tp., 1981).

Ibnu Taimiyyah, Taqyudin Abu al'Abbas Ahmad bin Abdul Halim, Majmu' al-ftāwa, (Cet III, tt: Dār al-Wafa', 2005).

Jonathan A.C. Brown, How We Know Early Hadith Critics Did Matn Criticism and Why It's So Hard to Find, Islamic Law and Society, 15 (2008) 143, www.brill.nl/ils.

Kamaruddin, Amin, Menguji Kembali Keakuratan Metode Kritik Hadis, Jakarta: PT Mizan Publika, 2009.

Manā’ al-Qattaan, Mbāhis fī 'Ulum al-Hadis, Maktabah al-Ma’arif, 2000, Cet. III.

Muslim, Imam, Sahih Muslim, Bairut: Dār Ikhya al-Turaś al'Arabi, tt.

Nabia Abbott, Studies in Arabic Literary Papyri II: Qur'ānic Commentary and Tradition, Chicago: University of Chicago Press, 1967.

Nasr Hamid Abu Zaid, Naqd al-Khitab al-Diniy, Kairo: Sina' Li alNasyr, 1992.

,Tahdits al-Islam Aw Aslamat al-Hadatsah? dalam buku Cosmopolitanism: Identity and Authenticity in the Middle east, Editor; Raul Mayer, Surrey; Curzon Press, 1st Edition. 1999.

al-Shaqafi al-Arabi, tt.

,Mafhum al-Nash, Dirosah Fi 'Ulum al-Qur'an, Beirut: Markaz ,dan Aster R. Nilson, 2004, Voice of an Exile: Reflections on Islam, London: Wesport Connecticut.

Nawir Yuslem, Ulumul Hadis, PT Mutiara Sumber Widya,2001. 
Riḍa, Muhammad Rasyid bin 'Ali, Tafsir al-Qur'an al-Hakim, alHai'ah al-Misriyyah al-Ammah li al-Kitab, 1990.

Rahman, Fazlur; Islam, Chicago, University of Chicago Press, Cet. II, 1979. , Major Themes of The Qur'an, Chicago, Bibliotheca Islamic, 1980.

Schacht, Joseph, the Origins of Muhammadan Jurisprudence, Oxford University Press, 1979.

Subkhi Shaleh,'Ulum al-Hadits wa Muștalahuhu, Bairut: Dār al'Ilmi, 1978.

William A. Graham, Divine Word and Prophetic Word in Early Islam, Netherlands, Mouton \& Co Printed, 1977. 
